\title{
O NEGATYWNEJ OCENIE MORALNEJ POSTĘPOWANIA DŁUŻNIKA I OSOBY TRZECIEJ JAKO PRZESLANCE SKARGI PAULIAŃSKIEJ
}

\section{UWAGI WSTĘPNE}

Przedmiotem rozważań podjętych w ramach niniejszego artykułu będą wybrane przesłanki skargi pauliańskiej; przede wszystkim przesłanka „pokrzywdzenia wierzyciela”, w mniejszym stopniu tzw. przesłanki podmiotowe, tj. „świadomość dłużnika” o krzywdzącym charakterze czynności oraz „wiedza” osoby trzeciej. Celem podjętych rozważań nie jest jednak przeprowadzenie możliwie wyczerpującej analizy tych przesłanek. Zarówno bowiem cywilistyka, jak i orzecznictwo poświęciły im już wiele uwagi, a co do właściwych rozwiązań wielu, jeśli nie większości bardziej szczegółowych problemów rodzacych się na tle wykładni art. 527 i n. k.c., panuje konsensus. W tym miejscu należy jedynie dla porządku przypomnieć, że ustawodawca wymaga między innymi, aby czynność prawna dokonana przez dłużnika z osobą trzecią powodowała pokrzywdzenie wierzyciela (art. 527 § 1 k.c.), które to „pokrzywdzenie” rozumiane jest jako powstanie po stronie dłużnika stanu jego niewypłacalności albo pogłębienie się niewypłacalności wcześniej już istniejącej (art. 527 $\S 2$ k.c.). Ustawa wymaga także, aby dłużnik, dokonując czynności prawnej z osobą trzecia, działał ze świadomościa jej krzywdzacego wierzyciela charakteru, a osoba trzecia o tym wiedziała (art. $527 \S 1$ in fine k.c.). Nie ma przy tym wątpliwości, że świadomość dłużnika powinna obejmować istnienie związku przyczynowego między dokonaną przez niego czynnością prawna, powstaniem jego niewypłacalności (pogłębieniem się niewypłacalności wcześniej już istniejącej) a uniemożliwieniem (czy przynajmniej znaczacym utrudnieniem) zaspokojenia się wierzycieli z jego majątku․ W opracowaniu postawione zostanie natomiast pytanie o rolę ocen moralnych dla kwalifikacji postępowania dłużnika (ewentualnie także osoby trzeciej) na gruncie przepisów konstruujących instytucję skargi pauliańskiej. Chodzi mianowicie o to, czy n e ga ty w n a

1 W nauce zob. zwłaszcza Pyziak-Szafnicka (2014): 1656; Gutowski (2017): 8; (2019): 1388; zob. także np. Sychowicz (2018): 1369 n.; Naczyńska (2018): 1145. W orzecznictwie zob. jednoznacznie m.in. wyroki SN: z 29 maja 2007 r., V CSK 77/07; z 18 stycznia 2008 r., V CSK 381/07; z 18 kwietnia 2012 r., V CSK 183/11; wyrok SA w Katowicach z 11 marca 2015 r., I ACa 1007/14, Lex nr 1665774 . 
(ewentualnie: przynajmniej indyferentna) ocena moralna postępowania dłużnika (ewentualnie również osoby trzeciej) stanowi konieczna, choć niewypowiedzianą wprost w obowiązujących przepisach przesłankę pozwalająca na ubezskutecznienie czynności prawnej dokonanej przez dłużnika z osobą trzecia. Udzielenie twierdzącej odpowiedzi na postawione wyżej pytanie prowadziłoby do wniosku, że wierzyciel nie będzie mógł żądać uznania za bezskuteczną wobec siebie czynności dłużnika, która spowodowała wprawdzie jego niewypłacalność (pogłębienie się niewypłacalności, art. $527 \S 2$ k.c.), lecz z jakichś względów postępowanie dłużnika (ewentualnie także osoby trzeciej) było zgodne z moralnością (w innym wariancie, gdy nie sposób dłużnikowi, ewentualnie także osobie trzeciej, postawić zarzutu postępowania niemoralnego). Dłużnik (a właściwie osoba trzecia), mogąc wykazywać dodatni moralnie charakter swojego postępowania (w innym wariancie: brak naganności moralnej swojego postępowania ${ }^{2}$ ), uzyskiwałby środek obrony, zmniejszający skuteczność skargi pauliańskiej.

Postawione pytanie wydaje się istotne $\mathrm{z}$ teoretycznego punktu widzenia. Nie chodzi tu bowiem tylko o typowy czy charakterystyczny dla dogmatyki spór o przyjęcie takiego czy innego wyniku wykładni obowiąujących przepisów prawnych, gdzie wchodzące w grę rozwiązania różnią się jedynie nieznacznie, a przyjęcie jednego z konkurencyjnych rozwiązań nie powoduje większych reperkusji w innych instytucjach prawa obowiąującego. Pytanie o rolę moralności dla skargi pauliańskiej zdaje się bowiem dotykać - wyrażając się nad wyraz nieściśle - istoty tej instytucji, determinując przynajmniej do pewnego stopnia sposób jej postrzegania na tle innych instytucji prawa obowiąującego. Postawienie tego pytania pozwoli też być może rzucić nieco nowego światła na przynajmniej dwa bardziej szczegółowe problemy: spełnienie przez dłużnika świadczenia na rzecz jednego z wielu wierzycieli oraz zabezpieczenie wierzytelności jednego z wielu wierzycieli. Jeśli przypuszczenie to okaże się trafne, zagadnienie postawione w opracowaniu okaże się nadto doniosłe praktycznie, a to wobec ogromnych problemów, jakie rodzi w orzecznictwie stosowanie przepisów o skardze pauliańskiej w skomplikowanych układach wielopodmiotowych.

\section{NEGATYWNA OCENA MORALNA DZIAŁANIA DŁUŻNIKA (OSOBY TRZECIEJ) Z PERSPEKTYWY DYREKTYW WYKŁADNI}

1. Już na wstępie prowadzonych badań należy podkreślić, że na gruncie językowych dyrektyw wykładni teza o konieczności ujemnej oceny moralnej postępowania dłużnika (osoby trzeciej) jako przesłance koniecznej skargi

${ }^{2}$ Dla zapewnienia większej przejrzystości rozważań będzie się dalej mówiło o negatywnej kwalifikacji moralnej postępowania dłużnika (osoby trzeciej), by powrócić do przedstawionego wariantu kwalifikacji indyferentnej w końcowych fragmentach rozważań. 
pauliańskiej byłaby przynajmniej prima facie trudna, jeśli nie niemożliwa, do obrony. Zdaje się bowiem, że ustawa nie wymaga żadnej tak czy inaczej w szczegółach rozumianej niemoralności po stronie dłużnika lub osoby trzeciej, w szczególności nie konstruuje zarzutu „działania moralnego”, który mógłby podnieść dłużnik (osoba trzecia). Przynajmniej więc prima facie przyjęcie tezy o dopuszczalności podniesienia takiego zarzutu stanowiłoby więc wykładnię zawężająca jednej z przesłanek i tak wąsko przez ustawodawcę skonstruowanej instytucji ${ }^{3}$, co wymagałoby wyjątkowo silnej legitymacji systemowej lub funkcjonalnej. Niemniej nie przesądzając w tym miejscu wyników dalszych rozważań, należy podkreślić, że samo postawienie problemu nie wykracza poza granice dopuszczalne na gruncie polskiej kultury prawnej, tym bardziej że skarga pauliańska „w tak wielu punktach odbiega od klasycznych figur prawa cywilnego, że niejednokrotnie konieczna jest szczególna interpretacja [przepisów tę instytucję konstruujących - K.M.]" ". W ramach dalszych rozważań problem zostanie zbadany nie tylko na gruncie językowych, systemowych i funkcjonalnych dyrektyw wykładni, lecz także - choćby w bardzo szkicowym zakresie - z perspektywy historycznej i prawnoporównawczej. Jest to szczególnie uzasadnione wobec konstatacji głoszącej, że polskie unormowania skargi pauliańskiej (zarówno w art. 288 k.z., jak i art. 527 i n. k.c.) można określić jako sprecyzowanie rozwiąań Kodeksu Napoleona - recypujacego z niewielkimi korektami rozwiazania justyniańskie ${ }^{5}$ - przy wykorzystaniu inspiracji z prawa niemieckiego, austriackiego oraz praktyki i nauki francuskiej ${ }^{6}$.

2. Patrząc na genezę i treść powództwa pauliańskiego w prawie rzymskim, można powiedzieć (uwzględniając wszakże jedynie opracowania o podręcznikowym czy przeglądowym charakterze ${ }^{7}$ ), że kształtowało się ono prawdopodobnie jako reakcja na podstępne (dolo malo) działania dłużnika i osoby trze$\mathrm{ciej}^{8}$. Negatywna ocena moralna działań dłużnika i osoby trzeciej (uzyskującej korzyść odpłatnie) podkreślana jest też właściwie w każdym opisie rzymskiej instytucji. Mowa jest w szczególności o działaniach „fraudacyjnych” (które rozumie się niekiedy jako równoznaczne z działaniami „podstępnymi”"10), „oszu-

${ }^{3}$ Przy czym wyjątkowy (i wąski) charakter skargi pauliańskiej jest rozwiązaniem koniecznym do przyjęcie w każdym systemie prawa cywilnego, zob. najszerzej Fiema (1937): 7 n. O wyjątkowym charakterze instytucji w orzecznictwie np. uchwałę SN z 22 stycznia 2009 r., III CZP 134/08, OSNC 2009, nr 12, poz. 161 z glosa A. Łuczyńskiej i A. Radwana, Lex/el. 2011.

${ }^{4}$ Pyziak-Szafnicka (2014): 1648, a także 1653 - o „niepowtarzalnym charakterze zjawisk” składających się na „pokrzywdzenie”.

5 O trwałości rzymskiej konstrukcji najszerzej Fiema (1937): 9.

${ }^{6}$ Dajczak, Giaro, Longchamps de Bérier (2018): 595.

7 Szeroką literaturę obcojęzyczną poświęconą skardze pauliańskiej w prawie rzymskim przywołuje Opinia Rzecznika Generalnego przedstawiona 21 czerwca 2018 r. w sprawie C-337/17 Feniks sp. z o.o. przeciwko Azteca Products \& Services SL, ECLI:EU:C:2018:487, <http://curia. europa.eu/juris/document/document.jsf?text=\&docid=203228\&doclang=PL\#Footnote10>.

8 Longchamps de Bérier (1998): 301.

9 Kuryłowicz, Wiliński (2016): 287; Kolańczyk (2007): 436; Rozwadowski (2008): 71 n.

10 Dajczak, Giaro, Longchamps de Bérier (2018): 594. 
kańczych”11, „nierzetelnych”12 czy „nieuczciwych”13. Podobnie na sprawę patrzono także dawniej, pisząc między innymi o „oszukańczym przewłaszczeniu majątku dla uniknięcia płacenia długów” ${ }^{14}$. Z drugiej strony, w ramach instytucji poprzedzających wykształcenie się skargi pauliańskiej w jej wersji ,justyniańskiej”, kwalifikacja prawna rozporządzeń dłużnika jego majątkiem była warunkowana ich moralnym bądź obyczajowym uzasadnieniem; nie podlegały zaskarżeniu czynności czyniące zadość obowiązkom moralnym bądź obyczajowym $^{15}$. Sugeruje to wyraźnie (jakkolwiek brak romanistycznych kompetencji piszącego te słowa skłaniać musi do ostrożności), że element niemoralności postępowania dłużnika (osoby trzeciej) stanowił przesłankę konieczną roszczenia pauliańskiego na gruncie prawa rzymskiego.

3. Pytanie o ewentualne prawne konsekwencje wykazania przez dłużnika (osobę trzecia) braku niemoralnego charakteru dokonanej czynności prawnej nie było expressis verbis stawiane w piśmiennictwie przedwojennym; zachowującym skądinąd w przeważającej mierze i dziś aktualnośćc ${ }^{16}$. Niemniej lektura reprezentatywnych wypowiedzi nauki z tamtego okresu wskazuje jasno, że niemoralny charakter postępowania dłużnika (osoby trzeciej, z wyjątkiem czynności uzyskiwanych nieodpłatnie) traktowany był nie tylko jako aksjologiczne uzasadnienie całej instytucji prawnej (jej ratio legis), lecz także jako kryterium zasadności (każdego poszczególnego) roszczenia przeciwko osobie trzeciej. Więcej, obie te okoliczności traktowane były niemal na pewno jako sprawy zupełnie oczywiste. Wedle Romana Longchamps de Bériera, głównego twórcy Kodeksu zobowiązań, skarga pauliańska zabezpieczać ma „sprawiedliwość i słuszność", a to dzięki sankcjonowaniu działań dłużnika i osoby trzeciej dokonanych w okolicznościach, w których można „zarzucić” tym podmiotom naruszenie „podstawowych zasad moralnych” przyjętych w obrocie ${ }^{17}$. Podkreślenie elementu niemoralności postępowania dłużnika (osoby trzeciej) jest tu bardzo dobitne. Podobnie na tle Kodeksu zobowiązań wypowiadali się inni autorzy. Najszerzej o konieczności sankcjonowania niemoralnego postępowania dłużnika (osoby trzeciej) pisał Józef Fiema, wskazując m.in., że „[w]zględom słuszności i sprawiedliwości odpowiada udzielenie wierzycielom, nie bioracym udziału w czynności, prawa reakcji przeciw czynnościom, które nie odpowiadają powyższym postulatom. Ze względu na to, że dłużnik przy wykonywaniu swojego prawa dopuszcza się nadużycia, szykany wobec wierzycieli, nadużycia stosunku zaufania w stosunku do nich, jego postępowanie musi być uznane za niezgodne z ogólnem poczuciem moralności i ogólnem porządkiem prawnym i dlatego usprawiedliwione jest odstapienie w takich wypadkach od zasady

11 Longchamps de Bérier (1998): 302.

12 Fiema (1937): $17 \mathrm{n}$.

13 Dębiński (2011): 297; Wołodkiewicz, Zabłocka (2014): 269.

14 Namitkiewicz (1949): 489.

15 Longchamps de Bérier (1998): 301.

${ }_{16} \mathrm{Na}$ co expressis verbis zwraca uwagę w kontekście „moralnych podstaw” skargi pauliańskiej Jasińska (2004): 49.

17 Longchamps de Bérier (1934). 
neminem laedit, qui suo iure utitur"18. Podobne myśli znaleźć można także w innych opracowaniach. Zatem „świadomość” dłużnika identyfikowano z jego „wina”19, a jego postępowanie kwalifikowano jako „nielojalne” ${ }^{20}$ czy „,szczególnie krzywdzace dla wierzycieli”21. Działanie osoby trzeciej (poza przypadkami uzyskania przysporzenia nieodpłatnego) uznawano za „naganne”22. Postawiona wyżej teza, wedle której negatywna ocena moralna postępowania dłużnika traktowana była zarówno jako ratio legis całej instytucji, jak i przesłanka konieczna każdego poszczególnego roszczenia przeciwko osobie trzeciej, znajduje nadto szczególnie dobitne uzasadnienie w fakcie, że spod zakresu przepisów o skardze pauliańskiej wyłączano na przykład datki dobroczynne świadczone przez dłużnika ${ }^{23}$, a więc czynności dodatnio oceniane moralnie.

4. Podkreślając szkicowość rozważań komparatystycznych, należy podkreślić, że w reprezentatywnych obcych kulturach prawnych moralna naganność postępowania dłużnika jest przynajmniej presuponowana w wypowiedziach określajacych ratio legis obowiązywania skargi pauliańskiej dla tych systemów prawnych ${ }^{24}$. Zatem w prawie niemieckim wskazuje się na świadomość, czy wręcz zamiar, „oszukania” wierzycieli ${ }^{25}$. Podobnie prawo francuskie sankcjonuje działania dłużnika dokonane dla „oszukania” wierzyciela ${ }^{26}$. Podejmując próbę syntezy europejskich systemów prawnych odnośnie do skargi pauliańskiej, Europejski Trybunał Sprawiedliwości uznał, że jest to instytucja stojąca „na straży minimalnych, ale i nieprzekraczalnych reguł uczciwego obrotu” 27.

18 Fiema (1937): 31.

19 O „swego rodzaju winie wobec wierzycieli” Korzonek, Rosenblüth (1936): 766 (za motywami do Kodeksu zobowiązań); podobnie Longchamps de Bérier (1948): 449.

${ }^{20}$ Korzonek, Rosenblüth (1936): 769 (za motywami do Kodeksu zobowiązań); Fiema (1937): 29; Longchamps de Bérier (1948): $450 \mathrm{n}$.

${ }^{21}$ Longchamps de Bérier (1948): 441.

22 Fiema (1937): $31 \mathrm{n}$.

${ }_{23}$ Zob. - jakkolwiek niestanowczo - Korzonek, Rosenblüth (1936): 771 (za motywami do Kodeksu zobowiązań).

${ }^{24}$ Ustawodawstwa obce przedstawia najszerzej Pyziak-Szafnicka (2014): 1634.

${ }_{25} \mathrm{~W}$ ustawodawstwie niemieckim instytucja skargi pauliańskiej uregulowana jest w ustawie szczególnej (Anfechtungsgesetz vom 5. Oktober 1994 [BGBl. I S. 2911], das zuletzt durch Artikel 3 des Gesetzes vom 29. März 2017 [BGBl. I S. 654] geändert worden ist), zdecydowanie bardziej szczegółowej niż rozwiązania polskie. Wprost o ochronie przed oszukańczymi działaniami dłużnika Nerlich, Niehus (2000): 11; obszerne omówienie wartości chronionych przez skargę pauliańską w prawie niemieckim zob. Kirchhof (2012): 2 n.

${ }^{26}$ Zob. art. 1167 Kodeksu Napoleona, wedle którego „wierzyciele mogą we własnym imieniu zaskarżyć czynności przez dłużnika na oszukanie ich praw zdziałane” (tłumaczenie: Longchamps de Bérier 1948: 442), któremu odpowiada obecnie (od 1 listopada 2016 r.) art. 1341-2, gdzie mowa o „działaniu w nieuczciwy sposób” i „świadomości oszustwa” (Le créancier peut aussi agir en son nom personnel pour faire déclarer inopposables à son égard les actes faits par son débiteur en fraude de ses droits, à charge d'établir, s'il s'agit d'un acte à titre onéreux, que le tiers cocontractant avait connaissance de la fraude).

${ }_{27}$ Zob. wyrok ETS z 10 stycznia 1990 r., Reichert $i$ Kockler, C-115/88, EU:C:1990:3. Zob. ostatnio także Opinia Rzecznika Generalnego przedstawiona 21 czerwca 2018 r. w sprawie C-337/17 Feniks sp. z o.o. przeciwko Azteca Products \& Services SL, ECLI:EU:C:2018:487, <http:// curia.europa.eu/juris/document/document.jsf?text=\&docid=203228\&doclang=PL\#Footnote10>. 
5. Zgodnie z reprezentatywnymi dla polskiej kultury prawnej koncepcjami wykładni, w tym zwłaszcza z koncepcja derywacyjna, proces wykładni powinien rozpoczać się od dyrektyw językowych. Relewantne dla prowadzonych tu rozważań wyrażenie „pokrzywdzić” (,z pokrzywdzeniem wierzyciela”) przynajmniej prima facie definiowane jest (równościowo) przez samego ustawodawcę w art. $527 \S 2$ k.c. Znaczenie nadane temu wyrażeniu jest, mówiąc nieco metaforycznie, ściśle techniczne; abstrahuje w każdym razie od problematyki ocen moralnych. Przypomnieć należy dla porządku, że czynność dokonana jest z pokrzywdzeniem wierzyciela wówczas, gdy „wskutek tej czynności dłużnik stał się niewypłacalny albo stał się niewypłacalny w wyższym stopniu, niż był przed dokonaniem czynności”. Znaczenie nadane przez ustawodawcę definicja legalna „wyprzedza” znaczenie przypisane przez reguły semantyczne języka ogólnego. Jest też ono zakładane we wszystkich właściwie opracowaniach doktrynalnych i wypowiedziach orzecznictwa, niemniej bodaj nigdy nie konfrontowano owego „technicznego” rozumienia z pytaniem postawionym na wstępie niniejszego opracowania ${ }^{28}$.

Mimo wskazanych wyżej okoliczności, można - jak się zdaje - wyrazić watpliwość, czy art. 527 § 2 k.c. rzeczywiście ustanawia „aż” (równościowa) definicję legalna „pokrzywdzenia”" ${ }^{29}$ czy też ,jedynie” definicję cząstkowa, zawierajacca postulat definicyjny (dla) tego wyrażenia. Po pierwsze, definicja ta - jeśli traktować ją jako definicję równościową - nie spełnia kryteriów technicznolegislacyjnych określonych w $§ 151$ Zasad techniki prawodawczej ${ }^{30}$. Jest to rzecz jasna argument niezbyt silny, wobec faktu dużo późniejszego skodyfikowania zasad techniki prawodawczej niż chwila ustanowienia art. 527 § 2 k.c. Niemniej niesporne równościowe definicje legalne w Kodeksie cywilnym - które występują zresztą nad wyraz rzadko - zredagowane są inaczej niż w przypadku art. $527 \S 2$ k.c., czego dobrym przykładem byłby art. 25 k.c. Po drugie, i jak się wydaje istotniejsze, tło historyczne i komparatystyczne wskazuje raczej, że dla prawodawcy rzeczą oczywistą była potrzeba sankcjonowania niemoralnego postępowania dłużnika wobec wierzycieli, a pytanie postawione na początku pracy prawdopodobnie w ogóle nie było przez twórców Kodeksu

28 Zob. zwłaszcza Pyziak-Szafnicka (2014): 1653; Gutowski (2017): 74; zob. także Karnicka-Kawczyńska, Kawczyński (1999): 19 n.; Wilejczyk (2012): 82 n.; Szanciło (2012): 11; Janiak (2014): 958; Haładyj (2017): 1289; Machnikowski (2017): 1107; Popiołek (2018): 236. W orzecznictwie zob. wyroki SN: z 13 lutego 1970 r., III CRN 546/69, OSNC 1970, nr 10, poz. 192; z 18 września 1998 r., III CKN 612/97, OSNC 1999, nr 3, poz. 56; z 7 grudnia 1999 r., I CKN 287/98; z 24 stycznia 2000 r., III CKN 554/98; z 6 czerwca 2003 r., IV CKN 204/01, OSNC 2004, nr 9, poz. 138; z 29 czerwca 2004 r., II CK 367/03; postanowienie SN z 8 grudnia 2005 r., II CZ 110/05; wyroki SN: z 13 października 2006 r., III CSK 58/06; z 15 lutego 2007 r., II CSK 452/06, OSNC-ZD 2008, nr 1, poz. 20; z 28 czerwca 2007 r., IV CSK 115/07; z 27 lutego 2009 r., V CSK 309/08; z 19 lutego 2010 r., IV CSK 303/09; z 11 maja 2012 r., II CSK 548/11, OSNC 2013, nr 2, poz. 19; z 17 stycznia 2017 r., IV CSK 194/16.

29 Teoretycznoprawnej kwalifikacji art. 527 § 2 k.c. jako definicji legalnej (równościowej?) dokonywano raczej wyjątkowo, zob. zwłaszcza Gutowski (2017): 73; w orzecznictwie wyrok SN z 18 kwietnia 2012 r., V CSK 183/11. Należy zauważyć, że kwalifikacja taka nie została dokonana przez Pyziak-Szafnicka (2014): $1651 \mathrm{n}$.

30 Rozporządzenie Prezesa Rady Ministrów z 20 czerwca 2002 r. w sprawie „Zasad techniki prawodawczej”, t.jedn.: Dz. U. 2016, poz. 283. 
rozważane. Wreszcie po trzecie, traktowanie definicji kodeksowych nie jako definicji równościowych, a cząstkowych przynajmniej bywa uznawane za dopuszczalne na gruncie językowych reguł wykładni. Modelowego przykładu dostarczają rozważania nad art. $77^{3}$ k.c. ${ }^{31}$ Dodać do powyższego należy jeszcze, że „dopisanie” przez wykorzystanie dyrektyw wykładni funkcjonalnej kryteriów moralnych do językowo rozumianych przesłanek określonego roszczenia przynajmniej bywa aprobowane w cywilistyce. Najlepszym przykładem wydaje się tu jeden z najpowszechniej reprezentowanych nurtów interpretacyjnych art. $446 \S 4$ k.c., wedle którego w przepisie tym wyrażone zostało domniemanie wyrządzenia krzywdy najbliższemu członkowi rodziny zmarłego, które może zostać obalone przez wykazanie braku jakichkolwiek związków uczuciowych między osobą zmarła a najbliższym członkiem jego rodziny. W konsekwencji status „najbliższego członka rodziny” okazuje się - wbrew supozycji językowej - przesłanką konieczna, lecz niewystarczająca dla powstania roszczenia o zadośćuczynienie pieniężne z tytułu śmierci „najbliższego członka rodziny”; konieczne jest tu także (założone przez ustawodawcę jako ratio legis instytucji, lecz niewyrażone expressis verbis) istnienie więzi uczuciowej między powodem a zmarłym ${ }^{32}$.

Nie widać więc fundamentalnych powodów, które by nakazywały traktować art. 527 § 2 k.c. jako równościową definicję „pokrzywdzenia”, a z której wynikałoby, że wierzyciel pokrzywdzony jest zawsze na skutek powstania stanu niewypłacalności dłużnika (pogłębienia się niewypłacalności i wystapienia innych przesłanek kodeksowych).

Uznanie za trafny poglądu, zgodnie z którym art. 527 § 2 k.c. przynajmniej może być rozważany w kategorii definicji cząstkowej, otwiera drogę do refleksji nad znaczeniem „pokrzywdzenia” w języku ogólnym. Zgodnie z regułami semantycznymi języka ogólnego „pokrzywdzony” to ten, komu została wyrządzona krzywda, tj. strata materialna lub moralna; wskazane konteksty użycia wyrażania to „bycie pokrzywdzonym przez los” lub „bycie niesprawiedliwie potraktowanym [przy podziale nagród]"33. Znaczenie wyrażenia ściśle wiąże je z „krzywdą, która na gruncie reguł semantycznych języka ogólnego znaczy tyle co „szkoda moralna, fizyczna lub materialna wyrządzona komuś niezasłużenie; także: nieszczęście, niesprawiedliwość, obraza dotykająca kogoś niesłusznie" "34. Jasny jest tu moment niemoralnego (niesprawiedliwego) działania różnie rozumianego „krzywdziciela”.

Nie tylko jednak „pokrzywdzenie” jako jedna z przesłanek skargi pauliańskiej winno być poddane badaniu na gruncie reguł językowych wykładni. Istotna wydaje się również „świadomość” (pokrzywdzenia) po stronie dłużnika. Autorka najobszerniejszej, reprezentatywnej dla współczesnej polskiej kultury prawnej pracy poświęconej skardze pauliańskiej wskazuje, że dłużnik może

31 Zob. zwłaszcza, z wyraźnie silniejszym jednak niż wyżej uzasadnieniem, Czepita, Kuniewicz (2019): $189 \mathrm{n}$.

32 Zob. zwłaszcza Druk sejmowy VI kadencji nr 81; w doktrynie Lackoroński (2009): 41; Nawracała (2011): 14; później jednoznacznie Mularski (2019): 889.

33 Szymczak (1996): 742, tak też 305.

34 Dubisz (2003a): 336. 
wykazać brak zasadności powództwa pauliańskiego pomimo swojej świadomości co do skutku, jaki spowoduje czynność prawna (tj. powstania niewypłacalności albo jej pogłębienia) między innymi wówczas, gdy brak mu odpowiednich zdolności umysłowych (jak należy sądzić, dla zrozumienia dalszych konsekwencji jego niewypłacalności dla interesów wierzyciela) lub przez udowodnienie, że ze względu na szczególną sytuację, w jakiej się znajdował, wniosek o krzywdzącym charakterze dokonywanej przez niego czynności prawnej jest, obiektywnie rzecz biorąc, nieuzasadniony. W pierwszym przypadku dowód zmierzałby do wykazania niepoczytalności; drugą sytuację można sobie wyobrazić, zdaniem autorki, zwłaszcza w odniesieniu do wierzytelności jeszcze niewymagalnych, albo gdy dłużnik oczekiwał określonych, w zasadzie pewnych dochodów ${ }^{35}$. O ile pierwsza z okoliczności mających wyłączać przesłankę „świadomości” jest uzasadniona w językowym znaczeniu wyrażenia „świadomość" (nie wchodząc w ogromną literaturę poświęconą zawiłym problemom związanym ze „świadomością”, można przyjąć w kontekście skargi pauliańskiej, że nie jest świadomy dłużnik, który nie jest w stanie zrozumieć związku przyczynowego między dokonaną czynnościa, powstaniem swojej niewypłacalności i niemożliwością zaspokojenia roszczeń wierzyciela), o tyle druga z tych okoliczności stanowi już funkcjonalne złamanie wyniku językowego. Chodzi bowiem o dłużnika, który jest świadomy powstania swojej niewypłacalności (i jej potencjalnych skutków dla wierzyciela), lecz który zarazem „liczy” jednak na to, że odzyska zdolność płatnicza. Zakładając, że owo „liczenie” miało uzasadnione podstawy, wspólną nicią byłby tu brak tak czy inaczej w szczegółach rozumianej winy po stronie dłużnika. Nawiasem należy podkreślić, że dość powszechnie przesłanka podmiotowa po stronie osoby trzeciej (art. $527 \S 1$ in fine k.c.) również jest interpretowana jako „zawiniony brak wiedzy”36. Jeśli przez winę rozumieć będziemy możliwość postawienia dłużnikowi zarzutu, staje się jasne, że ów brak możliwości postawienia dłużnikowi zarzutu (brak winy) będzie mógł wystapić nie tylko w przypadkach wskazanych przez Małgorzatę Pyziak-Szafnicka - nawet jeśli przypadki takie nie będą zbyt częste (klasy czy typy takich przypadków zbyt szerokie). Konkludując, element moralny (zarzucalność postępowania, wina) jakkolwiek nie wynika z językowego znaczenia „świadomości”, jest przez naukę wyraźnie zakładany w wykładni tego wyrażenia. Okoliczność, że element moralny zawęża językowe znaczenie „świadomości”, pozwalałaby - dla zachowania spójności - na wprowadzenie go również do „pokrzywdzenia”.

${ }^{35}$ Pyziak-Szafnicka (2014): 1658; do takich szczególnych przypadków należy też, zdaniem autorki, zaliczyć sytuacje, gdy zaskarżona czynność jest tylko współprzyczyną niewypłacalności, a pozostałe jej przyczyny były od dłużnika niezależne czy też niemożliwe do przewidzenia. Pogląd Pyziak-Szafnickiej był wielokrotnie powtarzany, ostatnio m.in. przez Machnikowskiego (2017): 1109; Haładyj (2017): 1293 n.

${ }^{36} \mathrm{~W}$ doktrynie jednoznacznie Jasińska (2004): 51; Szanciło (2012): 15; w orzecznictwie zob. np. wyrok SN z 28 listopada 1995 r., I CRN 218/95 (por. jednak wyrok SN z 30 kwietnia 1998 r., III CKN 629/97); podobnie wyroki SN: z 17 września 2003 r., II CK 10/02; z 6 listopada 2003 r., II CK 193/02; z 27 stycznia 2004 r., II CK 381/02. 
6. Najważniejsze z perspektywy podjętych rozważań wydają się jednak dyrektywy systemowe i funkcjonalne, powiązane zresztą ze sobą (a po części także z dyrektywami językowymi - wówczas gdy język wykorzystywany przez prawodawce jest nacechowany moralnie, zwłaszcza przy „pokrzywdzeniu" ${ }^{37}$ ) w trudny do ostrego rozdzielenia sposób. Na gruncie tych dyrektyw należy w pierwszej kolejności dostrzec, że jakkolwiek w szczegółach rozumiana niemoralność postępowania dłużnika (osoby trzeciej) jako przesłanka konieczna skargi pauliańskiej pojawia się we współczesnych wypowiedziach nauki i orzecznictwa, gdzie - podobnie jak to działo się w przeszłości i podobnie jak to dzieje się w innych systemach prawnych - potrzeba sankcjonowania niemoralnych działań dłużnika krzywdzących wierzyciela traktowana jest jako uzasadnienie zarówno obowiązywania całej instytucji prawnej, jak i ubezskuteczniania czynności prawnych w konkretnych stanach faktycznych. Mowa jest wielokrotnie (w obu tych kontekstach) o „czynnościach fraudacyjnych” ${ }^{8}$ czy „koluzji (zmowie)”39, jak również działaniu „oszukańczym”40, „nierzetelnym”41, „nielojalnym”42, „nagannym”43, „nieuczciwym”44, „niegodziwym”45, „sprzecznym z dobrymi obyczajami”46 itp. Odnotować można i takie

${ }^{37}$ Jest to zdecydowanie bardziej złożony problem. W uproszczeniu można powiedzieć, że dyrektywy funkcjonalne pozwalają wybrać jeden z możliwych rezultatów wykładni językowej, a w pewnych przypadkach umożliwiają odrzucenie wyniku (wyników) wykładni językowej. Dyrektywy językowe natomiast pozwalają odtworzyć wartości-cele i inne wartości z tekstu prawnego, które to wartości stanowią podstawę dyrektyw funkcjonalnych. Za zwrócenie uwagi na problem dziękuję Panu Piotrowi Klaczakowi.

38 Zob. Naczyńska (2018): 1131. W orzecznictwie zob. wyroki SN: z 13 października 2006 r., III CSK 58/06; z 27 lutego 2009 r., II CNP 108/08; z 20 października 2011 r., IV CSK 39/11; z 24 września 2015 r., V CSK 667/14, OSNC 2016, nr 7/8, poz. 94.

39 Zob. w różnych co do szczegółów kontekstach uchwałę SN (7) - zasada prawna z 11 października 1980 r., III CZP 37/80, OSNC 1981, nr 4, poz. 48; uchwałą SN z 6 lutego 1987 r., III CZP 103/86, OSP 1988, nr 3, poz. 57; wyroki SN: z 8 kwietnia 1998 r., III CKN 450/97, OSNC 1998, nr 11, poz. 184; z 24 października 2002 r., II CK 396/02, OSP 2003, nr 11, poz. 141; z 2 grudnia 2003 r., III CK 147/02.

40 Zob. Pyziak-Szafnicka (1996): 515; pogląd aprobuje Gutowski (2017): 62.

${ }^{41}$ Na gruncie Kodeksu zobowiązań: Fiema (1937): 17.

42 Kwalifikacja działania dłużnika jako „nielojalności” pojawia się zdecydowanie najczęściej, zob. Pyziak-Szafnicka (2014): 1622; Szanciło (2012): 5; Wilejczyk (2012): 75; Janiak (2014): 947; Haładyj (2017): 1281; Machnikowski (2017): 1104; Popiołek (2018): 228. W orzecznictwie zob. wyroki SN: z 12 grudnia 2001 r., III CKN 496/00; z 14 lutego 2008 r., II CSK 503/07; uchwały SN: z 12 maja 2011 r., III CZP 19/11, OSNC 2011, nr 12, poz. 132; z 12 maja 2011 r., III CZP 15/11, OSNC 2012, nr 1, poz. 1; wyroki SN: z 7 marca 2013 r., IV CSK 452/12; z 29 maja 2015 r., V CSK 454/14; z 14 stycznia 2016 r., IV CSK 289/15; wyrok SA w Katowicach z 11 marca 2015 r., I ACa 1007/14, Lex nr 1665774.

${ }^{43}$ Tak Pyziak-Szafnicka (2014): 1655; w orzecznictwie wyroki SN: z 11 grudnia 2013 r., IV CSK 222/13; z 14 stycznia 2016 r., IV CSK 289/15; wyrok SA w Katowicach z 11 marca 2015 r., I ACa 1007/14, Lex nr 1665774.

${ }_{44}$ Tak Pyziak-Szafnicka (2014): 1623; Haładyj (2017): 1281; Janiak (2014): 947; Popiołek (2018): 228; Naczyńska (2018): 1131. W orzecznictwie tak wyrok SN z 26 marca 2015 r., V CSK $320 / 14$.

45 Tak postanowienie SN z 6 grudnia 2017 r., V CZ 68/17.

${ }^{46}$ Haładyj (2017): 1281. Por. jednak wyrok SN z 18 kwietnia 2013 r., II CSK 557/12, OSNC 2014, nr 2, poz. 13. 
wypowiedzi, zwłaszcza Sądu Najwyższego, w ramach których, może niejednoznacznie, lecz jednak wskazuje się na brak podstaw uwzględnienia skargi pauliańskiej w przypadku, w którym dłużnikowi nie sposób postawić zarzutu postępowania niemoralnego ${ }^{47}$. Wskazać też można przynajmniej jedno orzeczenie, w którym tzw. poczucie sprawiedliwości powołane zostało, obok językowej treści przepisu, jako argument przemawiający za oddaleniem powództwa niestarannego wierzyciela ${ }^{48}$. W innym judykacie podkreślono natomiast konieczność brania pod uwage „zindywidualizowanych ocen”; różnych dla każdego poszczególnego stanu faktycznego i wyraźnie nawiązujących do problematyki moralnej ${ }^{49}$. Zdarzają się też, wprawdzie wyjątkowo, wypowiedzi o charakterze ogólnym, dość jednoznacznie udzielające twierdzącej odpowiedzi na postawione na wstępie niniejszego opracowania pytanie. Wedle najbardziej jednoznacznej spośród nich „bez możliwości postawienia zarzutu moralnego skarga pauliańska traci swe uzasadnienie" ${ }^{50}$. Podkreślić jednak należy, że spotkać można i takie wypowiedzi, które - jak się zdaje - wykluczają relewancję jakichkolwiek okoliczności w przypadku spełnienia się (dosłownie rozumianych?) przesłanek skargi pauliańskiej ${ }^{51}$.

Powyższe rozważania należy jeszcze uzupełnić o spostrzeżenie, że podobnie do postępowania dłużnika kwalifikowane jest także zachowanie osoby trzeciej ${ }^{52}$. W kontekście art. 527 § 1 in fine k.c. mowa między innymi o zachowaniach (czy wręcz „poczynaniach”53) „nagannych”54, podejmowanych „w złej wierze”55 czy „nielojalnych”

Należy z powyższego wnosić, że teza o możliwości podniesienia przez osobę trzecią zarzutu „zgodnego z moralnościa postępowania dłużnika (ewentualnie także samej osoby trzeciej)" jest zakładana także we współczesnej polskiej kulturze prawnej. Niemniej sam problem nigdzie nie został postawiony explicite,

${ }^{47}$ Zob. zwłaszcza wyrok SN z 29 maja 2015 r., V CSK 454/14; w podobnym kierunku ostatnio wyrok SA w Łodzi z 26 czerwca 2014 r., I ACa 1573/13 (wskazuje, że brak jest podstaw do uwzględnienia skargi pauliańskiej w sytuacji, gdy dokonywana czynność miała racjonalne uzasadnienie, a skutek krzywdzący był jedynie jej dodatkowym efektem). Aprobująco Haładyj (2017): 1301.

${ }^{48}$ Wyrok SN z 28 marca 2003 r., IV CKN 1965/00. Por. później podobnie wyrok SA w Łodzi z 5 marca 2013 r., I ACa 570/12, Lex nr 13120181.

49 Tak wyrok SN z 17 stycznia 2017 r., IV CSK 194/16; jak się wydaje podobnie wyrok SN z 14 czerwca 2017 r., IV CSK 470/16.

50 Tak Pyziak-Szafnicka (1996): 515; (2014): 1624.

51 Zob. zwłaszcza Popiołek (2018): 230.

52 Znak równości między moralną kwalifikacją postępowania dłużnika i osoby trzeciej wyraźnie stawiają wyroki SN z 11 grudnia 2013 r., IV CSK 222/13, oraz z 14 stycznia 2016 r., IV CSK $289 / 15$.

53 Tak wyrok SN z 3 lutego 2005 r., II CK 412/04.

${ }_{54}$ Tak Pyziak-Szafnicka (2014): 1658; Machnikowski (2017): 1109; w orzecznictwie wyroki SN: z 6 listopada 2003 r., II CK 193/02; z 3 lutego 2005 r., II CK 412/04; z 11 grudnia 2013 r., IV CSK 222/13; z 14 stycznia 2016 r., IV CSK 289/15; wyrok SA w Katowicach z 11 marca 2015 r., I ACa 1007/14, Lex nr 1665774.

55 Tak Gutowski (2017): 90; Popiołek (2018): 241; w orzecznictwie wyroki SN z 3 lutego 2005 r., II CK 412/04, oraz z 13 kwietnia 2011 r., V CSK 313/10.

56 Tak uchwała SN z 12 czerwca 2008 r., III CZP 55/08, OSNC 2009, nr 7/8, poz. 95; wyrok SA w Katowicach z 11 marca 2015 r., I ACa 1007/14, Lex nr 1665774. 
a sama teza pozostaje w sprzeczności ze ściśle „technicznym” sposobem rozumienia „pokrzywdzenia”. Wymagane jest więc przedstawienie bardziej pogłębionej argumentacji.

Należy zauważyć, że brak uwzględnienia elementu moralnego w wykładni art. 527 i n. k.c. prowadziłby (scil. mógłby prowadzić dla niektórych stanów faktycznych lub określonych typów stanów faktycznych) do sprzeczności między prawem a moralnością ${ }^{57}$. Kolizja taka raz, że uderzałaby w założenie o racjonalności aksjologicznej prawodawcy, dwa, jest przez tego prawodawcę rozstrzygana raczej na korzyść moralności (zwłaszcza w art. 5 k.c.). Oto bowiem postępowanie nie tylko niesprzeczne, ale i w pełni zgodne z moralnością (czy wręcz wymagane na gruncie norm moralnych) okazywałoby się niezgodne z prawem - a w każdym razie rodziło szczególnego rodzaju sankcję wymierzoną w podmiot działający w zgodzie z normami moralnymi. Cel instytucji skargi pauliańskiej, niespornie ugruntowany w moralności (sankcjonowanie niemoralnych działań dłużnika podejmowanych dla pokrzywdzenia wierzycieli), byłby w takich przypadkach (określonych klasach albo typach przypadków) definicyjnie podważony. Odmiennego stanowiska można by bronić tylko przy przyjęciu tezy, że postępowanie dłużnika, którego skutkiem jest jego niewypłacalność, jest zawsze niemoralne (czy, w słabszej wersji, nigdy nie może mieć uzasadnienia moralnego). Należy jednak podkreślić, że poprzedzanie kwalifikacji moralnych określonych zachowań wielkim kwantyfikatorem niemal zawsze (zawsze?) jest ryzykowne i prawie zawsze (zawsze?) można wobec ogólnej kwantyfikacji wysunąć przynajmniej bardzo poważne zastrzeżenia. Takie poważne zastrzeżenia wysuwane są nawet wobec prima facie niespornych i w tym czy w innym sensie fundamentalnych dla istnienia społeczeństwa norm moralnych (np. wobec normy „nigdy nie należy zabijać człowieka” takimi standardowo wysuwanymi zastrzeżeniami byłoby pytanie o obronę konieczna, czy - w szerszej perspektywie - o wojnę obronna). Teza o definicyjnej niemoralności postępowania dłużnika prowadzącego do pokrzywdzenia wierzycieli już z tego powodu nie wydaje się możliwa do obrony.

Z perspektywy rozważań poświęconych dyrektywom systemowym i funkcjonalnym należy jeszcze zadać pytanie o treść owych „norm moralnych”, o których wielokrotnie pisano w ramach niniejszego szkicu. Termin „norma moralna” pozostanie pozbawiony znaczenia, dopóty nie powie się, o jaka moralność chodzi. Nie wykluczając, że w wyjątkowych jakichś przypadkach dłużnik (a właściwie osoba trzecia) będzie mógł powołać się na zgodność swojego postępowania z moralnością ogólną czy powszechna, niemal jednolicie akceptowana w niemal całym społeczeństwie (zinternalizowana przez zdecydowaną większość członków tego społeczeństwa), o tyle w zasadzie chodzić będzie o moralność „uczciwego obrotu”, moralność akceptowaną przez przedsiębiorców działających na rynku. Dla ochrony „pewnych zasad o charakterze ogólnym, które wyznaczają minimalne, ale nieprzekraczalne reguły uczciwego

${ }^{57}$ Którą być może dostrzega wyrok SN z 14 czerwca 2017 r., IV CSK 470/16. 
obrotu"58, instytucja ta została przecież skonstruowana. Patrząc na problem z innej nieco perspektywy, można powiedzieć, że ochrona pauliańska zdaje się nie tyle nawet służyć sankcjonowaniu działań niemoralnych, ile ochronie założenia o dobrej wierze uczestników obrotu gospodarczego, przyjęcie którego to założenia jest konieczne do funkcjonowania nie tylko gospodarki, ale i całego społeczeństwa. Ochrona ta nie powinna więc być udzielana tam, gdzie założenie to nie zostało w najmniejszym stopniu naruszone.

\section{PRZYKŁADY ZGODNYCH Z NORMAMI MORALNYMI POSTĘPOWAŃ DLUŻNIKA KRZYWDZĄCYCH WIERZYCIELA}

Akceptacja tezy, że wierzyciel o tyle będzie mógł skutecznie zaskarżyć czynność prawną dłużnika z osobą trzecia, o ile postępowanie dłużnika (ewentualnie także osoby trzeciej) było sprzeczne z moralnością (a przynajmniej indyferentne moralnie), zmusza do zadania pytania o przypadki (klasy czy typy przypadków), w których dłużnik (osoba trzecia) będzie mógł podnieść zarzut działania zgodnego z moralnościa (indyferentnego moralnie). Wydaje się, że wskazać można dwie takie klasy (typy?).

W ramach pierwszej z klas (typów?) realizacja moralnego obowiązku prowadzi do zabezpieczenia, lub wręcz uratowania, dobra oczywiście ważniejszego niż interes wierzyciela, wyrażający się w możliwości zaspokojenia jego wierzytelności. Klasa taka będzie niezwykle wąska, chodzić może na przykład o dłużnika, który przekazuje osobie trzeciej korzyść majątkową umożliwiająca jej podjęcie leczenia ratującego zdrowie czy życie. Można tu też widzieć daleka analogię do art. 424 k.c. Nawet zreszta, gdyby nie podzielić tego poglądu, roszczenie wierzyciela przeciwko osobie trzeciej i tak zostałoby zapewne oddalone na gruncie art. 5 k.c. ${ }^{59}$

Pomijając scharakteryzowane wyżej, wyjątkowe zupełnie przypadki, zaproponowana teza może, jak się zdaje, rzucić odrobinę nowego światła na dyskusję dotycząca stanów faktycznych, w których osoba trzecia uzyskująca korzyść majątkową od dłużnika jest zarazem jednym z jego wierzycieli. Z góry należy zastrzec, że mowa tu o „rzuceniu odrobiny nowego światła na dyskusję”, a nie na wyczerpujące rozwiązanie problemu zaspokojenia przez dłużnika jednego z wielu wierzycieli na gruncie przepisów art. 527 i n. k.c. Jest to bowiem chyba najtrudniejsze dogmatycznie i najdonioślejsze społecznie zagadnienie

58 Tak Pyziak-Szafnicka (2014): 1630. Tak też Rachwał (2000): 61; podobnie Jasińska (2004): 49. Na gruncie Kodeksu zobowiązań zob. Fiema (1937): 6. W orzecznictwie zob. zwłaszcza wyrok SN z 18 kwietnia 2013 r., II CSK 557/12, OSNC 2014, nr 2, poz. 13.

59 Należy jednak zauważyć, że możliwość stosowania art. 5 k.c. nie jest oczywista, ponieważ niejednokrotnie to nie wierzyciel w sposób sprzeczny z zasadami współżycia społecznego korzysta ze swego prawa (wierzycielowi chodzi jedynie o zaspokojenie jego słusznego roszczenia), a decyduje o tym szczególny kontekst, w jakim osoba trzecia uzyskała korzyść majątkową. Wątpliwości co do stosowania art. 5 k.c. zdaje się, że wzmacniają tezę o konieczności niemoralnego (przynajmniej indyferentnego) charakteru postępowania dłużnika (osoby trzeciej). 
w ramach dyskusji nad skargą pauliańska, wymagające przynajmniej odrębnego studium. W tym miejscu można tylko podkreślić, że nie może być ono zbyte kilkoma fraz(es)ami powtarzanymi przez naukę i orzecznictwo (zwłaszcza $\mathrm{SN}$ ), które przy bliższej analizie okazują się wewnętrznie sprzeczne ${ }^{60}$, a trudności generowane przez to właśnie zagadnienia doprowadziły do propozycji zrezygnowania z - wydawałoby się koniecznej w każdym systemie prawa cywilnego - instytucji skargi pauliańskiej w bodaj najważniejszej z europejskich modelowych regulacji prawa cywilnego ${ }^{61}$. W tym miejscu można więc wyrazić jedynie bardzo ostrożne przypuszczenie, że kluczem do odpowiedzi na pytanie o zaskarżalność czynności prawnej, na podstawie której korzyść majątkowa uzyskał jeden z wierzycieli dłużnika, jest właśnie moralna kwalifikacja takiej czynności. Próbując sprecyzować powyższe, równie ostrożnie wyrazić można pogląd, wedle którego nie postępuje niemoralnie (a w silniejszej wersji, postępuje wręcz moralnie) taki dłużnik, który zaspokajając jednego z kilku wierzycieli i stając się niewypłacalnym wobec pozostałych, kieruje się racjonalnym rachunkiem ekonomicznym. Będzie się tak działo przynajmniej co do zasady wówczas, gdy spłata określonego wierzyciela nie stawia pozostałych wierzycieli w sytuacji gorszej, niż znaleźliby się oni w przypadku przeprowadzenia postępowania upadłościowego wobec dłużnika. Wydaje się również, że nie działa niemoralnie (działa moralnie) dłużnik, który zaspokaja wierzyciela, którego wierzytelność powstała przed powstaniem innych wierzytelności przeciwko niemu, zwłaszcza gdy późniejsi wierzyciele wiedzieli o istniejących wcześniej zobowiązaniach dłużnika. Podobnie nie działa niemoralnie (działa moralnie) dłużnik, który zaspokaja jednego z kilku wierzycieli nawet wówczas, gdy ich wierzytelności powstały równocześnie, niemniej dłużnik już w chwili ich powstania był niewypłacalny, a wszyscy wierzyciele o jego niewypłacalności wiedzieli. Powyższe należałoby, jak się zdaje, mutatis mutandis odnieść również do zabezpieczenia wierzytelności przysługującej jednemu z wierzycieli.

\section{WNIOSKI}

Na gruncie przeprowadzonych w ramach niniejszego opracowania badań można bronić zasadności tezy (a przynajmniej bronić zasadności potrzeby pogłębionej dyskusji nad tą teza), wedle której niemoralny (a przynajmniej

${ }^{60}$ Zwykle mówi się o niedopuszczalności „dowolnego uprzywilejowania jednego z wierzycieli” (tak np. wyroki SN: z 12 grudnia 2001 r., III CKN 496/00; z 5 lipca 2007 r., II CSK 118/07; podobnie wyrok SN z 23 listopada 2005 r., II CK 225/05, i ostatnio wyrok SN z 6 września 2017 r., I CSK 38/17, OSNC 2018, nr 7/8, poz. 80); zwrot ten będzie jednak pozbawiony jakiegokolwiek znaczenia, dopóty nie określi się „niedowolnych” reguł uprzywilejowania jednego z wierzycieli. Niejednokrotnie SN wskazuje wprawdzie na „kolejność wynikająca z ustawy lub umowy”, przechodząc jednak do porządku dziennego nad faktem, że żadna ustawa nie przewiduje żadnej kolejności zaspokajania wierzycieli poza postępowaniem egzekucyjnym (upadłościowym, restrukturyzacyjnym; zob. np. wyrok SN z 23 lipca 2003 r., II CKN 299/01; podobnie wyrok SN z 8 października 2014 r., II CSK 762/13).

${ }^{61}$ Von Bar, Clive, Schulte-Nölke (2009): 50. 
indyferentny moralnie) charakter postępowania dłużnika jest konieczną przesłanką skargi pauliańskiej. Przepis art. $527 \S 2$ k.c. traktowany byłby wówczas jako definicja cząstkowa - a nie równościowa - „pokrzywdzenia”; ewentualnie „świadomość” dłużnika byłaby rozumiana jako jego wina. W tym miejscu nie prowadzi to jeszcze do żadnych istotnych zmian w interpretacji przepisów konstruujaccych skargę pauliańska; podobne poglądy były entymematycznie zakładane na gruncie wielu wypowiedzi nauki i orzecznictwa dotyczacych w swej warstwie dosłownej innych problemów. Pojawia się jednak pytanie o konsekwencje dosłownego postawienia tych kwestii.

Bez watpienia domaganie się od wierzyciela przeprowadzenia dowodu niemoralnego charakteru działań dłużnika byłoby zupełnie bezpodstawne. Istnieja jednak dobre racje ku temu, by przyznać pozwanemu możliwość podniesienia zarzutu w pełni czy całkowicie moralnego postępowania dłużnika (w wersji silniejszej) lub postępowania niesprzecznego z normami moralnymi (w wersji słabszej). Akceptacja możliwości podniesienia zarzutu w wersji silniejszej wydaje się przy tym wręcz konieczna z perspektywy spójności aksjologicznej systemu prawnego; akceptacja zarzutu w wersji słabszej przynajmniej prima facie dość poważnie mogłaby ograniczyć (niejednokrotnie i tak wątpliwa) skuteczność skargi pauliańskiej jako instrumentu ochrony wierzycieli. Wydaje się więc, że dłużnik (osoba trzecia) mógłby podnosić jedynie zarzut w wersji silniejszej. Przyjęcie proponowanego w tym miejscu ostrożnie wyniku wykładni zapewniałoby również, jak się zdaje, odpowiedni balans w przyjmowanych konsekwencjach zastosowania pozajęzykowych dyrektyw wykładni w odniesieniu do przepisów konstruujących instytucję skargi pauliańskiej. Konsekwencje te bowiem z reguły (a jak się zdaje wręcz zawsze) prowadzą do poszerzenia przesłanek roszczenia pauliańskiego, zdecydowanie poprawiając pozycję wierzyciela, by wspomnieć o rozszerzeniu zakresu znaczeniowego „czynności prawnej” z art. 527 § 1 k.c. również na (niektóre) orzeczenia organów władzy publicznej czy rozszerzenie zakresu znaczeniowego „dochodzenia zaspokojenia z przedmiotów majątkowych” z art. 532 k.c. na dochodzenie zaspokojenia z całego majątku osoby trzeciej (zwłaszcza wówczas, gdy przedmiotem czynności fraudacyjnej były pieniądze lub przedmiot uzyskany od dłużnika nie jest już w posiadaniu osoby trzeciej). Gdyby uznać trafność powyższej argumentacji, art. $527 \S 2$ k.c. konstruowałby $\mathrm{w}$ istocie domniemanie (przy przyjęciu dość swobodnego rozumienia tego wieloznacznego terminu) niemoralnego postępowania dłużnika; domniemanie, które z jednej strony nie byłoby nieobalalne, z drugiej zaś - jego obalenie byłoby z pewnością bardzo trudne. W każdym razie, w przypadku zgodności postępowania dłużnika z normami moralnymi nie można byłoby uznać dokonania czynności prawnej za krzywdząca (relewantną pauliańsko), nawet jeśli doprowadziła do wskazanych przez ustawodawcę w art. $527 \S 2$ k.c. skutków.

Krzysztof Mularski

Uniwersytet im. Adama Mickiewicza w Poznaniu

mularski@amu.edu.pl

https: / /orcid.org/0000-0002-4664-9812 
Bar, Ch. von, Clive, E., Schulte-Nölke, H. (eds.) (2009). Principles, Definitions and Model Rules of European Private Law Draft Common Frame of Reference (DCFR). Münich.

Czepita, S., Kuniewicz, Z. (2019). Forma dokumentowa, [w:] Z. Radwański, A. Olejniczak (red.), System prawa prywatnego. Tom 2: Prawo cywilne - część ogólna. Warszawa: 188-196.

Dajczak, W., Giaro, T., Longchamps de Bérier, F. (2018). Prawo rzymskie. U podstaw prawa prywatnego. Warszawa.

Dębiński, A. (2011). Rzymskie prawo prywatne. Kompendium. Warszawa.

Dubisz, S. (red.) (2003a). Uniwersalny Słownik Języka Polskiego. Tom 2: K-Ó. Warszawa.

Dubisz, S. (red.) (2003b). Uniwersalny Słownik Języka Polskiego. Tom 3: P-Ś. Warszawa.

Fiema, J. (1937). O zaskarżaniu czynności dłużnika zdziałanych ze szkodą wierzycieli. Lwów.

Gutowski, M. (2017). Bezskuteczność czynności prawnej. Warszawa.

Gutowski, M. (2019). Artykuł 527-534, [w:] M. Gutowski (red.), Kodeks cywilny. Komentarz. Tom 2: Komentarz do art. 353-626. Warszawa: 1370-1417.

Haładyj, K. (2017). Artykuł 527-534, [w:] K. Osajda (red.), Kodeks cywilny. Komentarz. Zobowiązania. Część ogólna. Tom 3a. Warszawa: 1279-1310.

Janiak, A. (2014). Artykuł 527-534, [w:] A. Kidyba (red.), Kodeks cywilny. Zobowiązania. Część ogólna. Tom 3. Warszawa: 946-994.

Jasińska, M. (2004). Skarga pauliańska - istota idei zaskarżenia. Prawo Spółek 89(5): 48-56.

Karnicka-Kawczyńska, A., Kawczyński, J. (1999). Skarga pauliańska. Prawo Spółek 25(1): 18-32.

Kirchhof, H.P. (2012). Münchener Kommentar zum Anfechtungsgesetz. München.

Kolańczyk, K. (2007). Prawo rzymskie. Warszawa.

Korzonek, J., Rosenblüth, I. (1936). Kodeks zobowiązań. Komentarz. Tom 1. Kraków.

Kuryłowicz, M., Wiliński, A. (2016). Rzymskie prawo prywatne. Zarys wykładu. Warszawa.

Lackoroński, B. (2009). Zadośćuczynienie pieniężne za krzywdy wynikłe ze śmierci najbliższego członka rodziny na podstawie art. $446 \S 4$ k.c. Palestra 54(619/620): 19-28.

Longchamps de Bérier, F. (1998). Prawnospadkowe pochodzenie actio Pauliana? Czasopismo Prawno-Historyczne 50(1): 299-303.

Longchamps de Bérier, R. (1934). Uzasadnienie projektu kodeksu zobowiązań. Komisja Kodyfikacyjna. Podkomisja prawa o zobowiazzaniach. Zeszyt 4. Warszawa.

Longchamps de Bérier, R. (1948). Zobowiązania. Poznań.

Machnikowski, P. (2017). Artykuł 527-534, [w:] P. Machnikowski, E. Gniewek (red.), Kodeks cywilny. Komentarz. Warszawa: 1103-1117.

Mularski, K. (2019). Artykuł 446, [w:] M. Gutowski (red.) Kodeks cywilny. Komentarz. Tom 2: Komentarz do art. 353-626. Warszawa 2019: 877-892.

Naczyńska, J. (2018). Artykuł 527-534, [w:] M. Habdas, M. Fras (red.), Kodeks cywilny. Komentarz. Zobowiązania. Część ogólna. Tom 3. Warszawa 2018: 1129-1164.

Namitkiewicz, J. (1949). Kodeks zobowiązań. Komentarz dla praktyki. Część ogólna. Tom 1: Art. 1-293. Łódź.

Nawracała, J. (2011). Zadośćuczynienie za śmierć osoby bliskiej - wybrane zagadnienia. Rozprawy Ubezpieczeniowe 11(2): 39-50.

Nerlich, J., Niehus, Ch. (2000). Gesetz über die Anfechtung von Rechtshandlungen eines Schuldners außerhalb des Insolvenzverfahrens. München.

Popiołek, W. (2018). Artykuł 527-534, [w:] K. Pietrzykowski (red.), Kodeks cywilny. Komentarz. Art. 450-1088. Przepisy wprowadzające. Tom 2. Warszawa: 226-260.

Pyziak-Szafnicka, M. (1996). Glosa do wyroku SN z 19.10.1995 r., III CRN 40/95. Orzecznictwo Sądów Polskich 40(11): 514-517.

Pyziak-Szafnicka, M. (2014). Ochrona wierzyciela w razie niewypłacalności dłużnika, [w:] A. Olejniczak (red.), System prawa prywatnego. Tom 6: Prawo zobowiązań - część ogólna. Warszawa: $1619-1692$.

Rachwał, A. (2000). Niewypłacalność jako przesłanka zaskarżenia przez syndyka czynności prawnej upadłego, dokonanej z pokrzywdzeniem wierzycieli. Transformacje Prawa Prywatnego 3: 61-76.

Rozwadowski, W. (2008). Prawo rzymskie. Zarys wykładu wraz z wyborem źródeł. Poznań.

Sychowicz, M. (2018). Artykuł 527-534, [w:] J. Gudowski (red.), Kodeks cywilny. Komentarz. Zobowiązania. Część ogólna. Tom 3. Warszawa: 1357-1385. 
Szanciło, T. (2012). Istota skargi pauliańskiej na tle orzecznictwa sądowego. Przegląd Sądowy 21(9): $5-12$.

Szymczak, M. (red.) (1996). Słownik języka polskiego. Tom 2: L-P. Warszawa 1996.

Wilejczyk, M. (2012). Przesłanki skargi pauliańskiej. Studia Prawa Prywatnego 2(25): 73-88.

Wołodkiewicz, W., Zabłocka, M. (2014). Prawo rzymskie. Instytucje. Warszawa.

\section{ON THE NEGATIVE MORAL ASSESSMENT OF THE DEBTOR'S AND THIRD PARTY'S CONDUCT AS A PREMISE FOR ACTIO PAULIANA}

\section{Sum mary}

The paper presents the thesis according to which the immoral (or at least morally indifferent) nature of the debtor's action is a prerequisite for actio Pauliana. Consequently, the defendant (third party) may raise the defense of the debtor's moral behaviour. If the debtor's conduct complies with moral standards, the legal act could not be regarded as detrimental (relevant to actio Pauliana), even if it resulted in the creditor's detriment. The acceptance of the possibility of raising the defence seems necessary from the perspective of the axiological coherence of the legal system. Adopting the proposed interpretation result would also ensure an appropriate balance in the implications of the use of non-linguistic interpretation directives in relation to the provisions constructing the institution of the actio Pauliana. Should the accuracy of the above argument be acknowledged, Article 527 para. 2 of the Civil Code would, in fact, construct a presumption of the debtor's immoral behaviour. It would be difficult but not impossible to refute the presumption in practice.

Keywords: morality; actio Pauliana 